\title{
AKAR KEILMUAN ISLAM NUSANTARA ABAD KE XVI-XVIII
}

\section{Maftu'khan is Qiqy ${ }^{1}$ \\ Peneliti Islam Nusantara, Alumni PTIQ Jakarta}

\section{PENDAHULUAN}

Hingga saat ini nampaknya belum ada kata sepakat di antar para pengkaji maupun para peneliti, mengenai proses masuknya Islam ke wilayah Nusantara. Ketidaksepakatan ini dikarenakan terdapat pada banyak hal yang saling bertentangan diajukan olehmasing-masing pihak mengenai kapan tepatnya Islam masukke wilayah ini, siapa yang menyebarkannya pertama kali, danpada jalur mana paling dominan penyebaran dilakukan; sertadengan menggunakan pendekatan model pendekatan apa analisa dilakukan, sehingga agama Islam dapat berkembang sedemikian pesat dalam waktu yang relatif singkat pada masyarakat yang pada waktu itu sudah mempunyai peradaban maupun keyakinan tersendiri.

Dalam pelbagai teori yang dimunculkan, belum ditemukan titik temu antara satu teori dengan teori yang lain. Hal ini dikarenakan adanya sifat "sepihak" atas berbagai teori yang dikemukakan. Dalam artian satu teori lebih mengedepankan aspek-aspek tertentu dari permasalahan-permasalahan yang muncul di permukaan. Tentu saja hal ini mengesampingkan, bahkan cenderung untuk mematikan teori-teori lain yang tidak sejalan dengan teori yang dikemukakan oleh seorang ahli misalnya. Perbedaan di antara teori-teori tersebut secara tidak langsung juga akan berdampak pada perselisihan mengenai pemahaman tentang perkembangan ilmu pengetahuan keislaman di kawasan nusantara.

Apabila kita memperhatikan perkembangan faham keagamaan yang dianut masyarakat Islam Nusantara sekarang, maka kita akan menemukan satu kenyataan bahwa kebanyakan populasi yang mendiami kawasan ini bermadzhab Syafi'i dalam pelaksanaan ibadah-ibadah mahdhah-nya, berteologi dengan aliran teologi asy'ariyyah-

\footnotetext{
${ }^{1}$ Peneliti Islam Nusantara asal Kudus Jawa Tengah, alumni PTIQ Jakarta.
} 
maturidiyyah serta bertasawuf ala sufisme ghazalian. Kondisi seperti ini tentunya mengundang berbagai pertanyaan, di antaranya adalah dari mana sumber-sumber keilmuan yang di jadikan acuan serta siapa yang sebenarnya pertama kali merintis keilmuan keislaman tersebut? Trend-trend apa saja yang menjadikan suatu aliran lebih dominant dibandingkan aliran yang lain? Tulisan ini akan mencoba menjelaskan duduk permasalahan seputar polemic corak keislaman Nusantara dari sudut penelusuran kurun waktu.

Perkembangan ilmu pengetahuan Islam di pulau Sumatra telah sedemikian pesat sejak sebelum Jawa mengenal Islam. Setidaknya demikianlah anggapan pertama yang lebih dahulu jika kita membincangkan dua pulau bertetangga yang masing-masing sering mengklaim wilayahnya lebih islami dibanding lainnya. Di mana pada abad ke12 telah berdiri kerajaan Islam pertama di wilayah Nusantara di ujung utara Sumatera. Kerajaan tersebut adalah Peurlak atau yang dalam buku-buku tulisan asing sering di tulis dengan Plix, Perlix, atau Perlax. Kerajaan ini terletak di pantai timur Sumatra. Meski demikian dari kerajaan ini belum ditemukan sebuah karya tulis pun yang membahas satu disiplin ilmu tertentu dalam Islam. Nampaknya pihak kerajaan lebih intens dalam mengadakan hubungan dengan luar negeri baik hubungan ekonomi, perdagangan maupun politik. Raja pertama kerajaan ini adalah keturunan dari bangsawan asing dan pribuimi. Aliran keagamaan yang dianut secara resmi oleh kerajaan adalah Syiah, jika dikaitkan dengan peta politik Islam yang terjadi di Timur Tengah pada waktu itu. Karena tiada keterangan yang jelas, baiklah kita sepakati saja pengelompokan ini. Agak spekulatif memang, tetapi mengertikah Anda bahwa kebanyakan sejarahwan juga menggunakan cara ini dalam menganalisa dan memperkenalkan sebuah teori kepada khalayak. Bukan lagi menjadi rahasia bahwa memang terdapat kesulitan dalam menilai faham keagamaan atau aliran kepercayaan yang dianut oleh suatu komunitas masyarakat, namun kebanyakan sejarawan menggunakan metode spekulatif dan generalisasi untuk hal ini dengan tujuan 
memudahkan langkah-langkah mereka dalam penelitiannya. ${ }^{2}$

Selain kerajaan Peurlak di sekitar kawasan tersebut terdapat juga kerajaan Islam Samudera Pasai yang sebenarnya berdiri lebih awal dibanding kerajaan Peurlak. Pada awal pendiriannya, tahun 1128, Kesultanan Pasai dipimpin oleh seorang Laksamana Laut dari dinasti Fatimiyah Mesir yang bernama Nizamuddin al-Kamil, namun dalam sebuah ekspansi ke daerah Sampar Kanan dan Sampar Kiri sang Laksamana gugur. Pada tahun 1284, sebagai pengganti dinasti Fatimiyah yang berkuasa di Mesir, dinasti Mamaluk yang cenderung bermadzhab Syafi'i kembali mengirim dua delegasinya yaitu Syekh Ismail bersama Fakir Muhammad untuk menghilangkan pengaruh Syiah dan sekaligus mengambil alih kepemimpinan dan menguasai pelabuhan Pasai. Di sana mereka bertemu dengan Marah Silu, salah seorang tentara pasai yang akhirnya di nobatkan sebagai raja kerajaan Pasai pertama dan bergelar Sultan Malik al-Saleh.

Menurut Slamet Muljana, aliran keagamaan bermadzhab Syafi'i lebih mendominasi faham keagamaan di Samudra Pasai pada masa pemerintahan Sultan Malik al-Saleh saja, karena para penerusnya kurang begitu memperhatikan perkembangan madzhab ini. Bahkan putra keduanya sendiri menyeberang ke aliran Syiah dan mendirikan kerajaan sendiri di Aru Barumun dengan gelar sultan Malik alMansur. Hampir selama satu abad kerajan Samudera Pasai menjadi pusat pemerintahan Islam di kawasan Nusantara sebelum akhirnya berpindah ke Malaka. Namun setelah sekian lama kerajaan ini menjalankan roda pemerintahan, belum juga ditemukan satu karya tertentu yang membahas suatu disiplin keilmuan dalam Islam secara mendalam.

Nampaknya para ilmuwan yang ada pada waktu lebih cenderung untuk menulis peristiwa-peristiwa yang terkait dengan kehidupan di seputar istana beserta masalahmasalah kenegaraan sich. Hal ini dapat dilihat misalnya dalam Hikayat RajaRaja Pasai, yang ditulis setelah tahun 1350. Setelah berakhimya dominasi Kesultanan Pasai akibat serangan Majapahit, munculah kerajaan Islam selanjutnya yang meneruskan pemerintahan di kawasan tersebut. Kerajaan ini bernama Malaka yang

${ }^{2}$ Slamet Muljana, Prof. Dr., Runtuhnya Kerajaan Hindu Jawa Dan Timbulnya Negara-Negara Islam Di Nusantara, h. 130

Vol. 3 No. 1 April $2017 \quad$ Halaman $1-14$ 
didirikan oleh menantu raja Pasai terakhir, sekaligus menjadi raja pertama kerajaan dengan gelar Mugayat Iskandar Syah. Berhubung mertua dan raja pertama Malaka ini menganut aliran madzhab Syafi'i maka raja Malaka ini juga dianggap sebagai penganut aliran ini.

Meskipun pada masa kerajaan Malaka belum ditemukan sebuah karya keislaman yang membahas disiplin keilmuan pada bidang tertentu, namun pelaksanaan hukum Islam nampaknya sudah pernah dijalankan dengan seksama, setidaknya kondisi seperti ini dapat ditelusuri melalui Risalah Hukum Kanun yang disusun pada masa Sultan Muzaffar Syah, sultan keempat kerajaan Malaka. Undang-undang ini menyangkut banyak hal yang terkait dengan kehidupan masyarakat sehari-hari, bahkan sampai mengatur masalah perniagaan, jatuh-pailit, atau masalah-masalah lain yang terkait dengan masalah penanaman modal. Hal ini tentunya merupakan langkah awal yang belum pernah ditemukan pada pemerintahan kerajaan-kerajaan sebelumnya. Undang-undang ini dibuat untuk menertibkan aturan-aturan perdagangan. Di masa pada zaman tersebut, aktifitas transaksi internasional berpusat di pelabuhan Malaka. Antony Reid dalam Asia Tenggara Dalam Kurun Niaga 1450-1680 mendugà bahwa pemberlakuan Risalah Kanun ini juga diterapkan di pelbagai Negara Melayu; karena beberapa salinannya ditemukan di Riau, Pahang, Pontianak bahkan sampai ke Brunei. $^{3}$

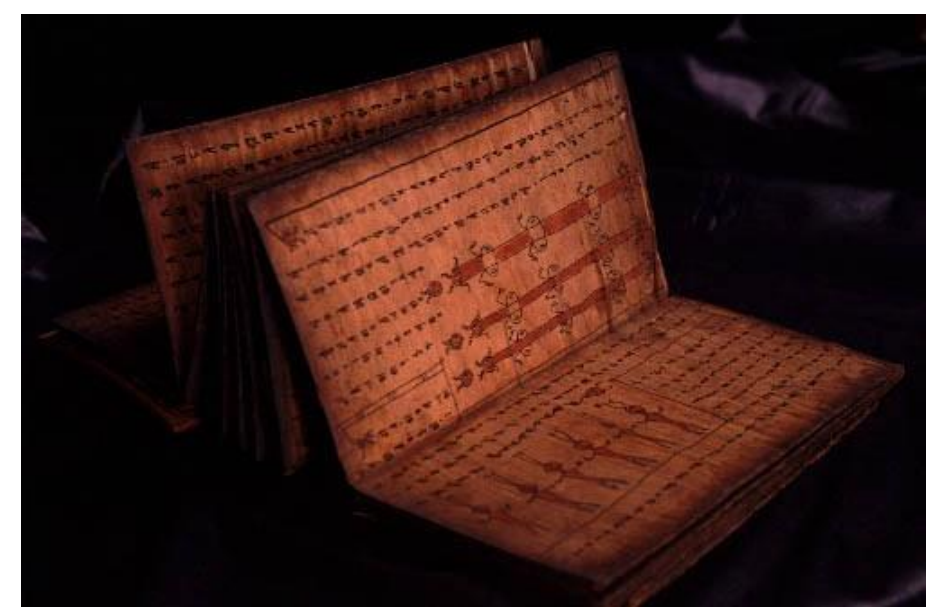

3 Antony Reid, Asia Tenggara Dalam Kurun Niaga 1450-1680, Jakarta: Yayasan Obor Indonesia, 1992, cet. I, h.163. 
Bukti lain yang mengatakan bahwa kerajaan Malaka pernah berusaha menerapkan hukum Islam adalah, keterangan dalam Undang-Undang Malaka yang menetapkan bahwa Malaka harus diatur sesuai dengan hukum al-Qur'an. Lebih jelasnya UndangUndang Malaka berisi berbagai unsur Islam di samping unsur aker istiadat aker. Unsur Islam ini sebagian besar bersumber dari ajaran Madzhab Syafi'I, bahkan sebagian dari undang-undang tersebut merupakan terjemahan dari teks kitab Taqrib karya Abi Syuja' yang merupakan teks standar fiqih syafiiyah.

Usia kerajaan Malaka ini cukup panjang, lebih dari satu abad kerajaan Malaka memainkan peranan penting menyangkut pelaksanaan kebijakan-kebijakan yang sudah diundangundangkan, sebelum akhimya dominasi ini direbut oleh bangsa Portugis. Bahkan pada tahun 1511 bangsa Portugis telah berhasil menguasai kawasan yang sangat strategis ini. Ketika doininasi Malaka mulai meredup, kerajaan Aceh dan Pidie yang pada waktu itu masih berstatus sebagai daerah taklukkan berhasil melepaskan diri dari cengkeraman kekuasaan kerajaan ini. Sultan Ali Mughayat Syah merupakan penguasa pertama yang berhasil membebaskan Aceh, sehingga menjadi kesultanan yang berdaulat sendiri. Sultan ini juga mempunyai jasa besar dalam mempersatukan daerahdaerah di semenanjung Sumatra bagian utara di samping juga mengambil alih peranan Malaka sebagai pemegang kebijakankebijakan penting akibat telah jatuhnya Malaka ke tangan bangsa asing. ${ }^{4}$

Eksistensi Aceh sebagai salah satu kerajaan Islam Nusantara berlangsung lama. Sejak rnulai berdirinya pada awal abad ke-16 sampai masa-masa lemahnya menjelang akhir abad ke-19. Di mana pada masa yang lama ini tentunya telah sering terjadi pergantian sultan yang bisa dijadikan acuan sejarah sebagai tolok ukur, baik mengenai sejauh mana kemajuan maupun kemunduran suatu kerajaan ketika dipimpin oleh seorang penguasa. Nampaknya para ahli sejarah sepakat bahwa masa kejayaan Aceh adalah sewaktu diperintah oleh Sultan Iskandar Muda yang memerintah antara tahun 1607-1636. Pada masa ini pulalah mentari keilmuan dan keislaman mulai terbit serta

\footnotetext{
${ }^{4}$ Marwati Djoened-Nugroho Notosusanto, Sejarah Nasional Indonesia, bag III, Jakarta : Balai Pustaka, eet-8,1994, hal.32.
} 
mendapat perhatian secara khusus oleh penguasa, walaupun sebenarnya benih-benih tumbuhnya kejayaan keilmuan ini sudah mulai nampak sejak Aceh dipimpin oleh Sultan 'Ala ad-din Ri'ayat Syah. Adalah seorang aktor intelektual sekaligus pengembara keilmuan bernama Hamzah al-Fansuri yang pada saat itu telah mampu membuahkan hasil karya di bidang keilmuan Islam.

Hamzah merupakan salah seorang ulama yang sudah malangmelintang di pusatpusat pengetahuan Islam seperti Makkah, Madinah, Yerusalem, dan Baghdad. Ia dianggap sebagai ahli sufi pertama Nusantara yang menulis buku-buku tentang tasawuf Islam. Lebih dari itu ia pula yang memperkenalkan kepada kita mengenai konsep tasawuf falsafi yang sering dibahas sebagai bahan kajian bagi para ahli pada masa-masa sesudahnya. Mengenai buah karya yang ditulis oleh Hamzah Fansuri, Naquib al-Attas mengungkapkan dalam Muqaddimah risalahnya:

Ia mampu menuangkan pendapatnya ke dalam bahasa Indonesia yang dapat dipahami. Ia juga dipandang sebagai penulis pertama dalam tasawuf dan kesusastraan sufi sepanjang sejarah Indonesia, yang menunjukkan kemampuannya dengan sempurna dalam pemikiran atau penalaran serta faham-faham yang dinisbatkan kepadanya. ${ }^{5}$

Dari hasil-hasil karyanya, Hamzah Fansuri nampaknya lebih aker pada dua bidang keilmuan. Pertama, tasawuf sebagaimana terlihat dalam kitab-kitabnya yang masih dapat kita jumpai hingga sekarang seperti Asrar al-'Arifin, Syarb al-'Asyiqin, alMuntaha dan al-Muhtadi. Ketiga kitab pertama berisi tentang pengesaan terhadap Tuhan, pengenalan serta pemahaman tentang Tuhan dan tingkah laku yang harus ditempuh oleh seorang salik untuk mencapai kemakrifatan terhadap Allah. Kedua, sastra Melayu, dengan karya-karyanya yang kebanyakan berupa syair antara lain Syair Burung Pingai, Syair Dagang, Syair Pangguk, Syair Sidang Faqir, Syair Ikan Tongkol dan Syair Perahu.

Ketika mengungkapkan gagasan serta ide-ide pemikirannya, Hamzah Fansuri

${ }^{5}$ Naqueb al-Attas, Tasawwuf al-Fansuri, h. 25

Vol. 3 No. 1 April $2017 \quad$ Halaman $1-14$ 
sering mengkorelasikan kedua disiplin keilmuan yang menjadi kemahirannya, hal semacam ini dapat dilihat misalnya ketika ia menjelaskan makna ayat faainamaa tuwalluu fatsamma wajhullah. Menurutnya "wajah Allah" dapat dipandang oleh makhluknya yang sudah mencapai derajat kesempumaan di mana saja makhluk tersebut berada. Menurut Fansuri, "Mahbubmu itu tiada berhasil, pada ainamaa tuwalluu jangan kau ghafil, fatsamma wajhullah sempurna wash, inilah jalan orang yang kainil."

Seorang ilmuwan lain yang sependapat dengan Hamzah Fansuri adalah Syamsuddin Sumatrani. Mereka berdua merupakan ulama sufi yang sangat berpengaruh di Kesultanan Aceh. Kedudukan mereka berdua di Kerajaan Aceh adalah Pemangku Jabatan Keagamaan Tertinggi di bawah kekuasaan Sultan sendiri. Sebagaimana al-Fansuni, Sumatrani juga mahir dalam ilmu sastra kebahasaan. Banyak karya dihasilkan oleh Sumatrani di antaranya Muhaqqina dan Syarh Rubba'i Hamzah Fansuri. Dalam bidang yang ditekuninya, tasawuf, Sumatrani dianggap sebagai pencetus konsep "martabat tujuh". Konsep ini mengajarkanb ahwa segala sesuatu yang ada di alam semesta merupakan aspek lahir dan hakikat yang tunggal, yaitu Tuhan. Tuhan sebagai yang mutlak tidak dapat dikenal baik oleh akal, indera maupun khayal. Dia baru dapat dikenal setelah ber-tajalli sebanyak tujuh martabat, sebelum akhirnya alam semesta beserta isinya tercipta. ${ }^{7}$

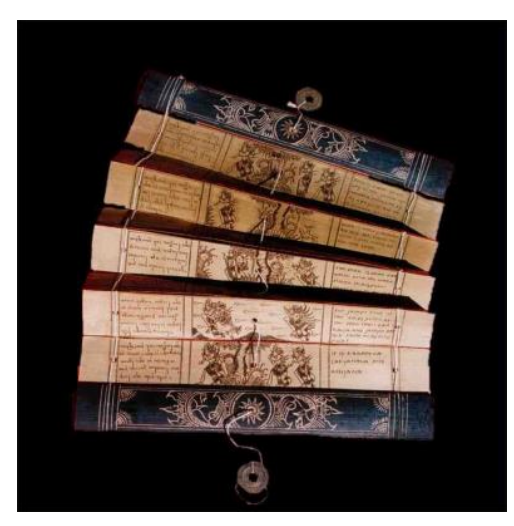

\footnotetext{
${ }^{6}$ Abdul Hadi W. M., ’Syaikh Hamzah Fansuri”, dalam Jurnal Ulumul Qur’an, No. 4 vol. 5 Th. 1994, h. 151

${ }^{7}$ Solihin, Melacak Peimikiran Tasawwuf di Nusantara, Jakarta : Raja Grafindo Persada, 2005 , hal.34
}

Vol. 3 No. 1 April 2017

Halaman $1-14$ 
Jika berbicara tentang kedua tokoh ini, kita pasti tidak akan luput dan pembicaraan tentang tokoh lain yang bersebrangan mengenai pemahaman keagamaan dengan mereka, yakni Nuruddin al-Raniri. Dialah tokoh yang sering disejajarkan sebagai tandingan penolak faham-faham tasawuf wujudiyyah yang merupakan inti dan ajaran tasawuf Hamzah al-Fansuri dan Syamsuddin Sumatrani. Ajaran ini, menurut alRaniri dianggap telah menyimpang dari rambu-rambu syariat. Selain penentang tasawuf wujudiyah, al-Raniri juga dianggap sebagai penulis pertama disiplin ilmu Fiqih di Nusantara. Meskipun karyanya, Shiroth al-Mustaqim, hanya menjelaskan aspekaspek ibadah mahdlah yang meliputi wudlu, sholat, zakat, haji, dan qurban namun kitab yang disajikan dalam bahasa Melayu dengan tulisan Arab ini banyak dikaji oleh masyarakat dan dijadikan landasan tata cara pelaksanaan ajaranajaran syariat dengan benar, di tengah-tengah semaraknya faham tasawuf yang bersifat eksesif dan spekulatif.

Menurut al-Raniri, ketika seseorang akan menjalankan ajaranajaran syariat Islam maka ia harus terlebih dahulu mengerti sumberaslinya, yakni al-Qur'an dan Hadis. Untuk itulah ia menyusunsebuah kitab hadis yang diterjemahkan ke dalam bahasa Melayu agar mudah dipahami oleh masyarakat pada zamannya. Kitab tersebut adalah Hidayat al-Habib fi al-Targhib wa al-tarhib yang di dalamnya ia sering menginterpretasikan hadis-hadis dengan ayat al-Qur'an, guna memperkuat karakter atas hadis-hadis yang diajukan.

Ketika membicarakan tentang sosok al-Raniri, para sejarahwan serta para pengkaji wacana keislaman menganggap bahwa seorang Ar-Raniri tidak hanya mumpuni dalarn satu bidang ilmu pengetahuan, karena ia dianggap sebagai perintis pertama beberapa cabang ilmu pengetahuan keislaman. Hal ini mungkin lebih disebabkan kepandaian ar-Raniri dalam mengemas ajaran serta wacana-wacana keislaman yang sebenarnya sudah ada pada masa sebelumnya. Menjadi satu bahasan secara spesifik, disamping bahasa yang disajikan dirasa lebih membumi.

Sementara pada bidang pengetahuan Islam yang erat hubungannya dengan kitab suci al-Qur'an, yakni tafsir, perhatian kita nampaknya harus rela dialihkan ke sosok ulama lain, Abdul Rauf al-Singkili. Beliau merupakan orang alim pertama di kepulauan Nusantara yang bersedia mengemban tanggung jawab besar mempersiapkan tafsir al- 
Qur'an 30 juz secara utuh. Karya ini oleh Abdur Rauf diberi nama Tarjuman alMustafid. Sebagai tafsir paling awal, tidak mengherankan apabila karya ini beredar luas di wilayah Nusantara, bahkan edisi tercetaknya dapat ditemukan di kalangan komunitas Melayu di tempat sejauh Afrika Selatan. Tafsir ini juga banyak memberikan sumbangan kepada telaah Tafsir al-Qur'an di Nusantara di samping juga menjadi jembatan antara terjamah dan tafsir, dan oleh karenanya mendorong telaah lebih lanjut atas karya-karya tafsir berbahasa Arab.

Abdul Rauf al-Singkili, selain mahir dalam bidang tafsir, ia juga dianggap sebagai perintis fiqih komprehensif pertama di Nusantara berkat karyanya, Anwar alThullab, yang mengemukakan berbagai aspek kehidupan masyarakat dalam bidang muamalat baik masalah yang terkait kehidupan politik, faktor ekonomi, dan aspekaspek kehidupan lainnya. Referensi utama yang di gunakan dalam karyanya ini adalah kitab Fath alWahhab karya Zakariya al-Anshari, seorang faqih terkenal dalam madzhab Syafii.

\section{JAWA DAN NUSANTARA BAGIAN TIMUR}

Perkembangan keilmuan Islam di pulau Jawa tidaklah segeimilang yang ada di kepulauan Sumatra. Untuk menggambarkan kondisi ilmu pengetahuan Islam yang ada di Jawa, ada baiknya kita memperhatikan ungkapan Maritin Van Bruinessen :

kitab-kitab yang dipelajari sebelum abad ke-20 di Jawa, wawasannya lebih sempit jika dibandingkan dengan wawasan intelektual pengarang-pengarang Islam dari daerah lain pada masa sehelumnya. Dalam karangan Nuruddin alRanini, Yusuf al-Makassar dan Abdul Rauf Singkel kita menemukan menemukan referensi kepada kitab-kitab yang jauh lebih banyak variasinya, dan lebih menarik secara intelektual. ${ }^{8}$

Dan peryataan tersebut kita dapat menelusuri perjalanan keilmuan Islam dan

${ }^{8}$ Martin Van Bruinessen, Kitab Kuning, Pesantren dan Tarekat, Bandung: Mizan, cet III, h. 30 
masa kekuasaan kerajaan Islam pertama pada abad ke-16 sampai abad ke-19.sedangkan mengenai catatan sejarah peran walisongo yang konon sedemikian besar dalam proses penyiaran dan penyebaran agama Islam di pulau Jawa, dapat dilihat dari sumbersumber sejarah Jawa yang dijadikan acuan tentang hal ini. Tak terlalu banyak menyimpan perdebatan yang signifikan. Dalam Babad Tanah Djawi, dinyatakan bahwa penyebaran agama Islam di pulau Jawa dilakukan oleh para wali songo, para pengarang Babad ini tetap bertahan dengan pendapat mereka bahwa agama Islam telah didakwahkan di pulau ini oleh kesembilan mubaligh yang dianggap sebagai orang saleh. Walaupun para wali boleh dikatakan berhasil dalam proses dakwah mereka, namun para wali pada waktu itu dianggap belum dapat menghasilkan karya keilmuan secara spesifik, rata-rata mereka menuangkan pemikiran ke dalam bentuk tembang dan serat. Hal ini dapat kita jumpai pada spesialisasi para wali pada jenis tembang tertentu, Sunan Giri misalnya dianggap sebagai pencipta tembang Jawa, Pucung dan Asmaradana, sedangkan Maskumamabang dan Mijil diciptakan oleh Sunan Kudus, sementara Sunan Muria menggubah tembang Jawa jenis Sinom dan Kinanti. Rata-rata tembang beserta serat tersebut berisi tentang wejangan dan nasehat-nasehat keagamaan. $^{9}$

Ada beberapa naskah yang menggambarkan alam pikiran umat Islam Jawa pada abad ke-16. Naskah karya-karya tersebut dua di antaranya masih tersimpan baik di negeri Belanda yang diduga ditemukan pada waktu pelayaran orang-orang Belanda di sepanjang pesisir utara pulau Jawa, kemungkinan besar saat berlabuh di Sedayu, jawa Timur. Naskah ini diterima pada bulan November 1597 oleh ahli perpustakaan di Leiden bernama Merula dan seorang pedagang Amsterdam bernama Van Dulmen. Naskah yang dimaksud di sini adalah kitab Sunan Bonang atau juga sering di sebut

${ }^{9}$ Karya ini mengalami peninjauan kembali selama beberapa kali pada abad ke-17 dan ke-18. Pernah disunting oleh J.J Meinsrna dalam dua jilid untuk Koninklijk Instituut Voor Taal, Land- en Volkenkunde van NederlandsechIndie tahun 1874-1877. 
dengan ”Wejangan Syeh Bari”.

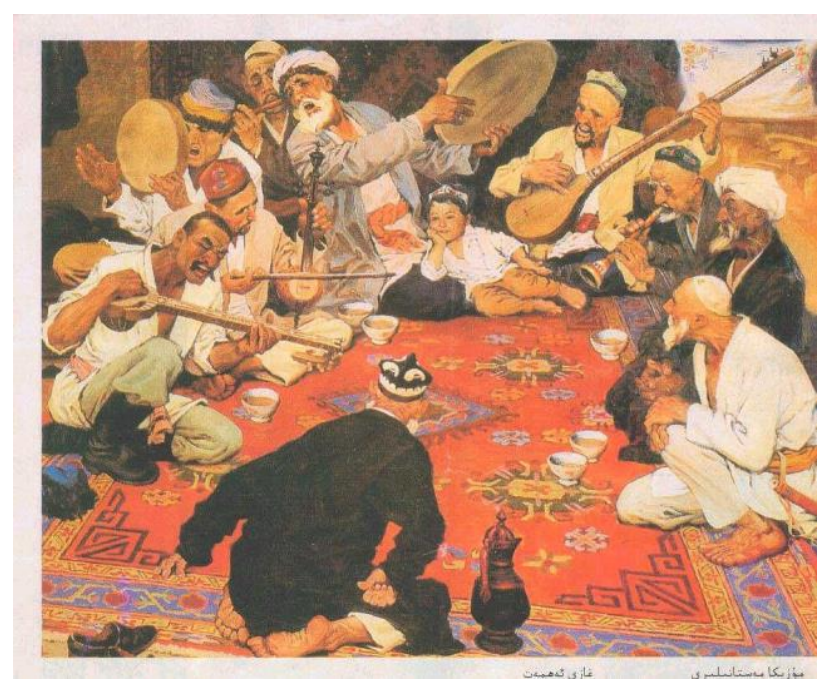

Kegiatan menulis yang dilakukan Sunan Bonang dapat ditentukan antara tahun 1475-1525. naskah tersebut ditulis olehnya dalam menyikapi ajaran-ajaran sufi heterodoks atau menyimpang dan kerpercayaan resmi, yang misalnya menyatakan bahwa apa yang ada adalah Allah, dan apa yang tidak ada adalah Allah; bahwa ketiadaan Allah adalah tak menciptakan dan hal itu menjelaskan kemahasucian Allah, sebab Allah itu sendirian dan kesepian, dan hanya diketahui oleh ketidakadaan yang mengitarinya. Sunan Bonang menentang dan menyatakan bahwa Allah lebih dari gambaran yang didefiinisikan tersebut. Allah Maha Tinggi dan Maha Luhur, Dzat Maha Suci yang tidak didahului oleh ketiadaan, juga tidak diiringi ketiadaan dan tidak pula dikelilingi oleh ketiadaan. Dari keterangan ini, dapat diketahui bahwa sejak permulaan Islam di pulau Jawa, renungan mistik sudah hidup, baik dalam bentuk pemahaman sufi yang ortodoks maupun heterodoks.

Naskah Islam lain pada abad ke-16 yang tertulis dengan bahasa Jawa namun tidak diketahui pengarangnya kemudian disebut primbon. Naskah ini berisi doa-doa, jampi-jampi, azimat-azimat, firasat, tafsir mimpi, serta ajaran-ajaran agama Islam. Mulai dari perdebatan-perdebatan yang dianggap sepele seperti penekanan ungkapan niat bagi seseorang yang akan mengambil air wudhu. Terkadang dalam naskah-naskah semacam ini dilampirkan juga petuah-petuah para leluhur yang karena telah beriklim 
islam tentu saja dimulai dari leluhur yang telah sah dianggap beragama Islam. Kendati demikian tidak jarang justru beberapa kalimat klangenan malah dinisnatkan kepada para penyebar agama Islam seperti petuah-petuah Syekh Ibrahim Maulana. Di mana Beliau ini mungkin sekali adalah Malik Ibrahim yang wafat pada tahun 822 H/1419 M. yang makamnya terdapat di Gresik.

Masih terdapat beberapa naskah lagi dari Jawa yang dibawa ke Belanda. Di antaranya kitab berbahasa Arab tentang fiqih, yaitu at-taqrib karya Abu Syuja' alAsfihani (dengan terjemahan bahasa Jawa antar babnya) dan kitab al-Idhah fi al-Fiqh. Hal ini menunjukkan bahwa kitab-kitab klasik berbahasa Arab sudah dikenal dan dipelajari pada abad ke-16 meskipun putra pribumi pada waktu itu belum ada yang menyusun satu kitab pun yang secara spesifik membahas aspek-aspek kehidupan yang ada hubungannya dengan ajaran Islam.

Satu abad sepeningal Walisongo, keilmuan keislaman di Jawa tidak mengalami perkembangan yang cukup signifikan. Selain sedikitnya peninggalan karya tulis dan kaum cendekia, para penyebar Islam pada waktu itu nampak sibuk dengan agenda perpaduan antara nilai-nilai subtansial agama Islam dengan aker aker. Pada waktu itulah unsur-unsur agama yang berasal dari Islam ortodoks dimasukkan ke dalam sastra Jawa. Adapun sintesis unsur-unsur antara tradisi Jawa lama dengan Islam mendapat sokongan kuat dari kerajaan Mataram pada awal abad ke-17. Naskah-naskah yang dianggap diilhami oleh sintesis ini meliputi Suluk Sukarso, Suluk Wijil, Serat Cibolek, Centini, Hidayat Jati dan lain sebagainya. Pada masa selanjutnya terbitlah kitab serat windu (kitab ajaran suci) yang mengumumkan ajaran Islam yang banyak kemasukan unsur-unsur Jawa tradisional.

Pengaruh walisongo dalam wacana keislaman pada masa tersebut diteruskan oleh Sultan Agung yang memerintah kerajaan Mataram di daerah Yogyakarta dari tahun 16 13-1645. Jasa sultan Agung terhadap perkembangan keilmuan Islam adalah inisiatifnya ketika meresmikan tahun Muslim-Jawa baru yang didasarkan pada peredaran bulan, ini terjadi pada tahun Saka 1555. Oleh karena itu, tahun ini menjadi tahun pertama dari aker penanggalan MuslimJawa baru. Dengan menggunakan penanggalan model ini, namanama bulan dan hari Hijriyah seperti Syawal dan Jumu'at 
secara otomatis menjadi ungkapan-ungkapan masyarakat Jawa dalam kehidupan sehari-hari.

Walaupun penguasa Muslim Jawa cenderung menjadi pendukung ilmu pengetahuan Islam, serta memasyarakatkan tradisi keilmuan Islam, namun kemunculan seorang tokoh yang Kapabel dalam bidang keilmuan Islam harus menunggu waktu yang cukup lama. Hingga baru pertengahan akhir abad ke-17 lahirlah seorang ulama yang nantinya dianggap sebagai alim yang berani melawan hegemoni kerajaan dalam wacana keislaman. Syeh Mutamakkin merupakan ulama sekaligus intelektual yang sering dijadikan aker perlawanan kaum neosufisme kepada pemerintah.

Di sini penulis tidak akan membahas pergulatan pemikiran yang terjadi pada waktu itu antara Mutamakkin dengan Ketib Anom (ulama yang mewakili pemerintah). Keseriusannya dalam mencari pengetahuan keagamaan tidak perlu diragukan lagi, karena ia termasuk para pendahulu ulama Jawa yang pernah berguru kepada ulama Timur Tengah. Di bidang pegetahuan agama inilah Syeh Mutamakin juga meninggalkan karya berharga berupa kitab yang isinya mecakup aspek syariat, akidah dan hakikat.

Meskipun karya ini tidak spesifik membahas suatu kajian keilmuan secara spesifik namun kanya ini cukup membangunkan generasi-generasi sesudahnya, ini terbukti semakin banyaknya ulama-ulama Jawa pada masa-masa berikutnya yang banyak menghasilkan karya-karya mereka di bidang pengetahuan keagamaan. Sebut saja misalnya Ronggowarsito, kemudian dilanjutkan lagi pada masa-masa berikutnya oleh Syeh Nawawi al-Bantani, Syekh Mahfuz at-Termasi dan masih banyak ulamaulama lainnya yang ikut mewarnai perkembangan pengetahuan keagamaan menjelang abad ke-20 di Nusantara umumnya dan pulau Jawa pada khususnya.

Sementara dari wilayah Nusantara bagian timur, meskipun Islam telah menyebar ke kawasan ini mencakup wilayah Ternate, Tidore, Makasar dan daerahdaerah lain di sekitarnya pada abad ke-16, namun tradisi keilmuan keagamaan belumlah menjadi hal yang krusial di sana. Adalah syekh Yusuf al-Makassari dan Syekh Arsyad al-Banjari yang sering di sebut para sejarahwan ketika menampilkan ulama dari pulau selain Jawa dan Sumatera. Melalui karyanya, Safinat al-Najaa, yang menjelaskan 
tentang ajaran-ajaran syariat, Syekh Yusuf al-Makassari pantas disejajarkan dengan tokoh-tokoh lain Nusantara yang telah mendunia. Karyanyaini, walaupun ditulis di Srilangka pada saat pembuangannya setelah dianggap mengobarkan pemberontakan besarbesaran di Banten terhadap Belanda, namun karya tersebut menyebar ke seluruh wilayah Nuasantara dan telah mendapat legitimasi kuat dan guru-gurunya yang berada di Haramain Karenanya kitab ini menjadi salah satu kitab standar di pesantrenpesantren hingga saat ini.

Sementara Syekh Arsyad al-Banjani dengan karyanyaSabil al-Muhtadin yang merupakan syarah dan kitab Siraat al-Mustaqim karya Nuruddin al-Raniry melanglang buana di pemerintahan kerajaan Banjar sebagai Qodhi Agung. Ia berhasil membumikan hukum-hukum aker setempat untuk berintegrasi dengan hukum-hukum syariat Islam. Hal ini misalnya dikemukakannya ketika membahas permasalahan warisan. Di mana di sebutkan di dalamnya sebuah kasus seorang wanita yang bekerja dengan suaminya, tiap hari dengan menggunakan perahu untuk mencani kayu aker di hutan. Sementara suaminya pergi ke hutan, dia tetap berada di perahu untuk memasak danmenyiapkan kebutuhan-kebutuhan lain. Pada saat suaminya meninggal, syekh Arsyad al-Banjari memberikan keputusan hukum, bahwa sang istri berhak mendapatkan pembagian yang separoh dan harta yang dihasilkan oleh keduanya. Artinya sebelum harta waris peninggalan suami dibagi, sang istri berhak mendapatkan bagian separoh dari hasil kerja mereka berdua semasa sang suami hidup bersamanya.

Tahkim semacam ini tentunya tidak akan terjadi di dunia Islam Arab mengingat iklim hubungan patriatkal yang sangat kental dalam masyarakat Arab. Syekh Arsyad membuat suatu terobosan yang sangat menarik untuk dicermati. 